\title{
POLLEN MORPHOLOGY OF SOME EUROPEAN ROSACEAE
}

\author{
TJ. REITSMA \\ (Botanical Museum and Herbarium, Utrecht)
}

(received February 17th, 1966)

\section{Abstract}

In this preliminary investigation attention was paid to pollen morphology of West-European species of the Rosaceae. Some new terms were used like fastigium, endocingulus etc. The terminology of Iversen and Troels-Smith has been followed in addition to improvements by Erdtman. A key is given to the types and subtypes for the use of pollen analytical investigators. Sanguisorba officinalis appeared to be always 3-colporate and not 6-colporate.

\section{INTRODUGTION}

It is well known that different types of pollen grains are found in the Rosaceae. FAEgri and Iversen (1964) mention some in their key to the N.W. European pollen types, e.g. Crataegus type, Potentilla type, Geum type. From pollen analytical investigations there appear to be more present types than the three above.

The object was to form pollen morphological types, which are easily distinguishable from each other by constant differences. These types have been worked up into a key for the use of pollen analytical investigators.

Within the types it was sometimes possible to give a key to the included genera or species. In these keys use is made of less constant and distinctive differences such as the length, the shape etc.

\section{Materials and methods}

\subsection{Flowers}

Pollen grains were obtained from herbarium material at the Botanical Museum and Herbarium of Utrecht, and from freshly collected flowers. Only flowers which just bloomed or are about to bloom are useful.

\subsection{Treatment of the pollen grains}

Pollen grains from fresh flowers were treated with the acetolysismethod of ERDTMAN (1943). If only a little material was present and this is especially so in the case of herbarium material, the micro-method described by PunT (1962) has been used.

\subsection{Preservation}

For the preservation of the grains the paraffin-method with the improvements by PUNT (1962) has been used, viz. the use of a granule of clay to support the cover-glass. This prevents large grains from being compressed. 


\subsection{Microscopes}

The pollen grains have been studied with a Leitz Ortholux binocular (obj. pl. apo öl 100/1.32, oc. periplan $10 \times$ ) and an Olympus phasecontrast microscope. This microscope was found very useful in detecting the configuration of the structural elements.

\subsection{Drawings}

The pollen grains have been drawn in such a manner that in one drawing as many characters as possible are to be seen at the same time. Each drawing therefore is midway between scheme and a photographical reproduction. The pollen grains have been drawn to scale, without a camera lucida or other drawing instruments.

The enlargment is $2000 \times$ except Mespilus viz. $1000 \times$.

\subsection{Photographs}

Microphotographs were made with a Leitz Orthomatcamera and Ortholux microscope apochr. obj. $\times 40, \times 63$ and an eyepiece $\times 10$.

\section{TERminology}

In principle the terminology of IVERSEN and Troels-SMITH (1950) has been followed, although in addition improvements by Erdtman have been used (see also PUNT, 1962). At the same time some terms have been used, which need a new or altered description:

Aperture (FAEGRI and IVERSEN, 1950)

A thinning or missing of a part of the sexine or nexine

Columellae index-C.I.

The ratio between the maximum height of the exine to the maximum height of the columellae

Costa pl. costae (FAEGri and Iversen, 1950)

Thickenings of the nexine

Costae colpi: Thickened nexine below the edge of colpi

Costae Endocinguli: Thickened edges of the endocingulus

Costar endocolpi: Thickened edges of the endocolpus

COSTAE ENDOPORI: Thickened edges of the endoporus

Costae pori: Thickened nexine below the edge of pori

Ectoaperture (VAN CAMPO, 1958)

A thinning or a missing of a part of the sexine e.g. colpus, porus

Endoaperture (VAN CAMPO, 1958)

A thinning or a missing of a part of the nexine

\section{Endocingulus}

Endoaperture, forming a band round the equator, of which the diameter is perpendicular to the axis of the ectoaperture.

Endocolpus (ZAGWIJN, 1963)

Endoaperture, of which one of the axes of the aperture is perpendicular to an axis of the ectoaperture. Length: breadth $>2$ 
Endoporus (ZaGwiJN, 1963)

Endoaperture, of which one of the axes of the aperture is perpendicular to an axis of the ectoaperture. Length: breadth $>2$

Membrana granulata (ERDTMAN, 1952)

Colpus or porus membrane (= nexine) with some scattered structural elements.

Membrana nudata (ERDTMAN, 1952)

Colpus or porus membrane (= nexine) without structural elements

Nexine (ERDTMan, 1948)

The inner, non-sculptured part of the exine

Sexine (ERDTMAN, 1948)

The outer sculptured part of the exine

Fastigium pl. Fastigia (= Atrium Punt, 1962)

Cavity, inside colporate grains, caused by the separation of the nexine and the domed sexine in the area of the endoapertures. Punt (1962) named this an atrium. This term, however, has been used by Pflug in a publication by Thomson and PfLug (1953) for triporate Tertiary pollen grains. Consequently it is not advisable to use this term here.

The shapes of the pollen grains in polar and equatorial view are described according to the system of KUYL, MULler and WATERBolk (1955).

The system of ERDTMAN (1952), which is based on the relation between the polar axis and the equatorial axis $(P: E)$ in equatorial view, is also used.

The length of the longest axis has been indicated in the description. This measurement, which may be either the equatorial or the polar axis, is an exact indication of the size of the pollen grain.

\section{KEY TO THE TYPES}

1 a Pollen grain with striae. . . . . . . . . . . . . . . . . 2

b Pollen grain without striae, that is psilate, echinate, scabrate, or only with phase contrast microscope striate . . . . . . . . . . 7

2 a Pollen grain operculate. . . . . . . . . . . . . . . 3

b Pollen grain not operculate . . . . . . . . . . . . . 4

3 a Pollen grain without costae colpi ......... Potentilla type

b Pollen grain with costae colpi . . . . . . . Rosa gallica type

4a Striae indistinct, intrastriate . . . . . . . . . . . 5

b Striae distinct, extrastriate . . . . . . . . . . . . . 6

5 a Pollen grain with costae colpi ....... Rubus idaeus type b Pollen grain without costae colpi . . . . . . . Crataegus type

6 a Pollen grain with tectum . . . . . . . . . . Geum type b Pollen grain with tectum perforatum ....... Mespilus type

7 a Pollen grain without structural elements on tectum . . . . . 8

b Pollen grains with structural elements on tectum . . . . . . . . . 12

8 a Pollen grain operculate . . . . . . . . . . . . . . . . . 9

b Pollen grain not operculate . . . . . . . . . . . . . . 10

9 a G.I. $>4$, pollen grain with costae colpi . . . . Rosa canina type

b C.I. $<3$, pollen grain without costae colpi . . . . Sanguisorba type

10 a C.I. $<3$, columellae in intercolpium higher than those at the poles

b C.I. $>4$, columellae in intercolpium as high as those at the poles 11 
11 a Pollen grain with costae colpi . . . . . . . Rubus idaeus type

b Pollen grain without costae colpi . . . . . . . Crataegus type 12 a Structural elements small: scabrae; endocolpus . . . Filipendula type b Structural elements large: echinae, gemmae, or verrucae; endoporus .............. Rubus chamaemorus type

\section{Results}

\subsection{General}

The pollen grains of the studied Rosaceae show a number of types, which can be distinguished clearly from each other. However, they all represent variations on the same theme.

They all are tricolporate. That both tricolpate and stephanocolporate pollen grains occur, can be looked upon as a normal variation.

The shape in equatorial view varies from prolate $(P: E=1.33-2)$ to suboblate $(P: E=0.88-0.75)$ and is mostly oval to rhomboidal. In some cases the shape is rectangular to compressed oval (Alchemilla type). The shape in polar view is mostly circular to semiangular, sometimes intersubangular (Alchemilla type) or subangular (Mespilus type). The colpi are usually narrow, sometimes broad (Sanguisorba officinalis subtype). In some types the colpi are accompanied by costae colpi (Alchemilla type, Rosa canina type, Rosa gallica type, Rubus idaeus type). Opercula can be present (Potentilla type, Sanguisorba type, Rosa canina type, Rosa gallica type). The polar area index (P.A.I.) ranges from 0.1 to 0.55 . Costae endocolpi or endopori are sometimes present (Rosa rubiginosa subtype, Geum subtype).

The Rosaceae studied are all striate, both extra- and intrastriate. The last structure is mostly only visible with the phase-contrast microscope. The striae on the tectum are formed by some strong, more or less fused, capita. Columellae, however, do not occur in striae. Mostly all the grains have a tectum, except Mespilus, which has a tectum perforatum.

On the tectum structural elements of different shape may be found such as scabrae (Filipendula type), echinae, verrucae or gemmae (Rubus chamaemorus type). All these grains have a fastigium, which is also found in other tricolporate grains e.g. Sedum, Solanum, Fabaceae p.p., Apiaceae p.p.

\subsection{Description and discussion}

Crataegus type (Faegri and Iversen, 1964) $\quad$ Figs. 1, 2

Diagnosis: tricolporate; fastigiate; psilate; intrastriate, mostly only visible with phase contrast; C.I. $>4$; subprolate-suboblate; eq. view: oval-rhomboidal; pol. view: circular-semiangular; max. length: $23-42 \mu$.

Absent: operculum; costae colpi.

Species studied

Crataegus monogyna Jacq.

Crataegus oxyacantha $\mathbf{L}$.

Aronia melanocarpa (Michx.) Ell.

Sorbus aria (L.) Crantz

Sorbus aucuparia $\mathbf{L}$.

33912B, [U]; Gulperberg

071886B, [U]; Utrecht

Wassenaar

$115592 \mathrm{~B}$, [U]

Utrecht 
TJ. REITSMA
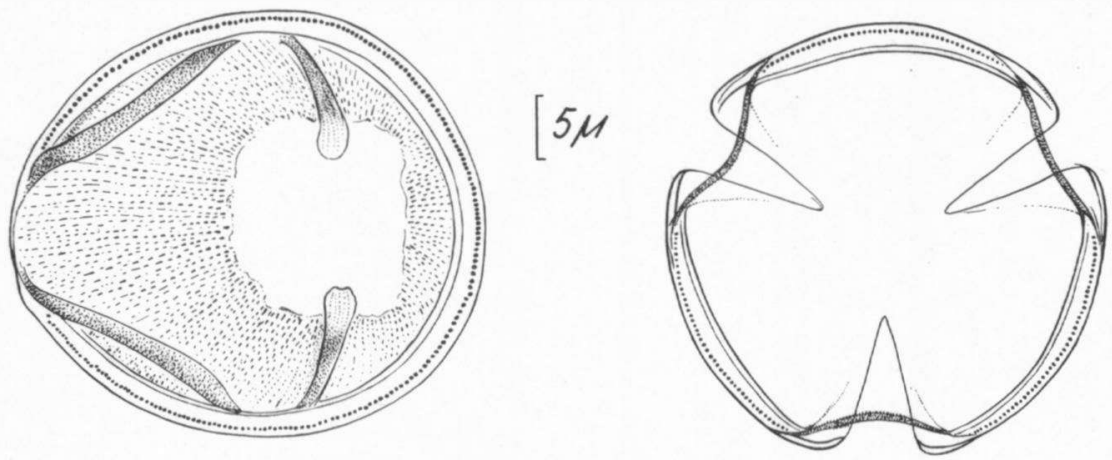

Fig. 1. Crataegus monogyna Jacq.
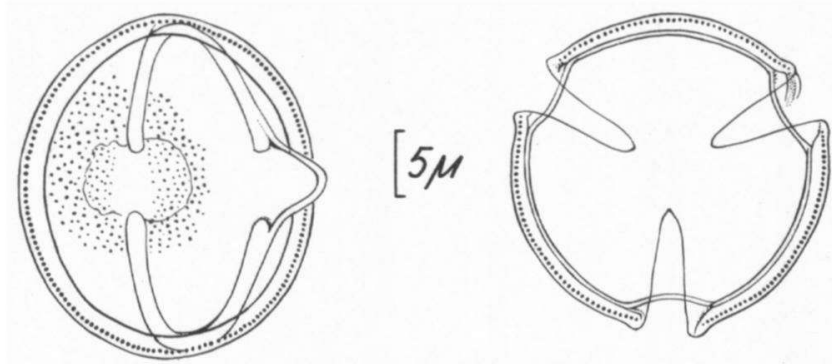

Fig. 2. Sorbus aucuparia L.

Mespilus type

Fig. 3

Diagnosis: tricolporate (tricolpate); fastigiate; striate; tectum perforatum; C.I. $>4$; oblate spheroidal-prolate spheroidal; eq. view: oval-rhomboidal; pol. view: circular-subangular.

Absent: operculum; costae colpi.

Species studied

Mespilus germanica L.

P.A.I.: $0.2-0.3$ : maximum length: $42-49 \mu$.

011015 [U]; Onderste Bos (Epen)

Rubus idaeus type

Figs. 4, 5

Diagnosis: tricolporate; fastigiate; psilate; intrastriate, mostly only visible with phase contrast; costae colpi; C.I. $>4$; prolate spheroidalsubprolate; eq. view: oval rhomboidal; pol. view: circular.

Absent: operculum.

KEY TO THE SUBTYPES

1 a Pollen grain with costae endocolpi. . . Rosa rubiginosa subtype

1 b Pollen grain without costae endocolpi . . . Rubus idaeus subtype

\section{Rubus idaeus subtype}

Plate IA

Diagnosis: max. length: $24-40 \mu$; P.A.I.: 0.1-0.35;

Species studied 

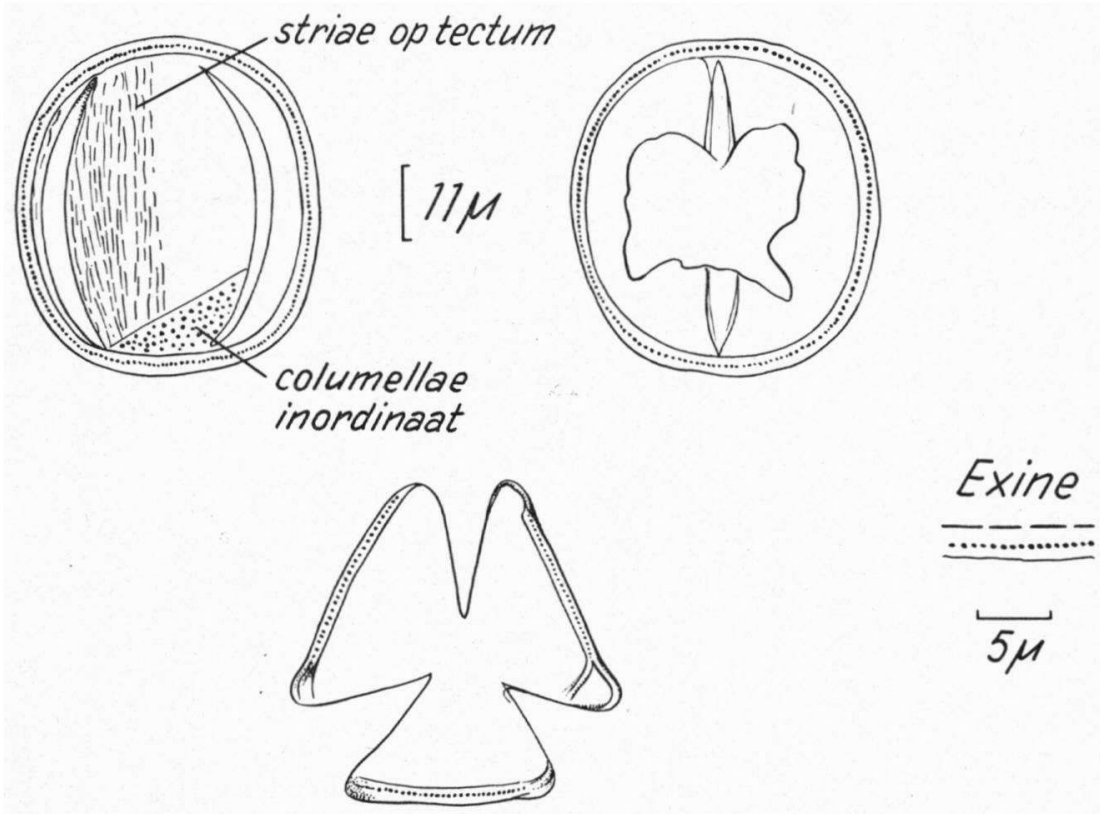

Fig. 3. Mespilus germanica $\mathbf{L}$.
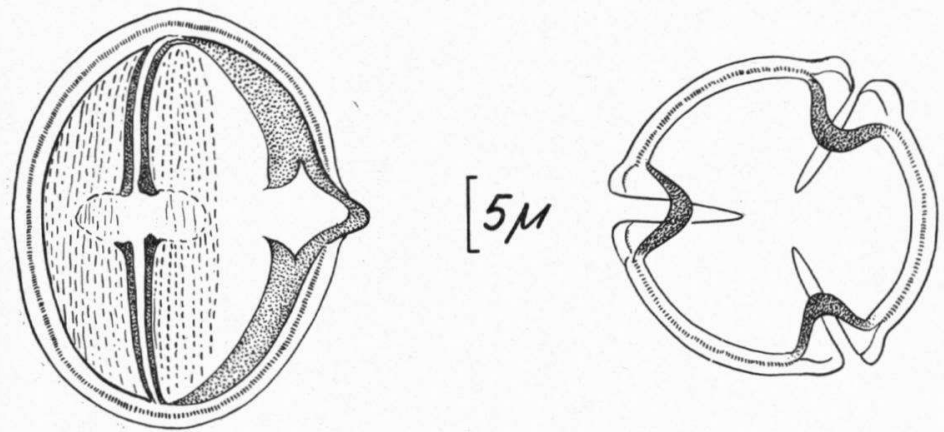

Fig. 4. Rubus tdaeus L.
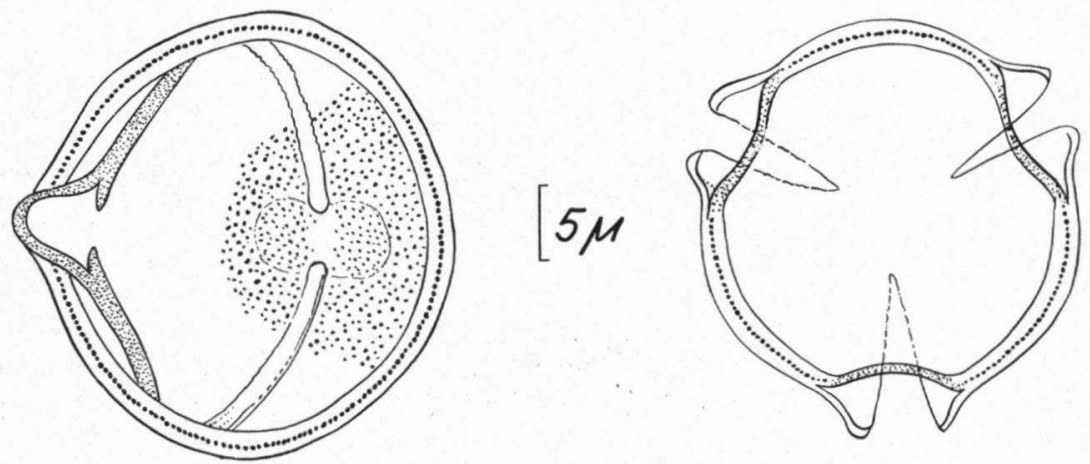

Fig. 5. Rosa arvensis Huds 
Rubus idaeus L.

Rubus saxatilis $\mathbf{L}$.

Rubus adornatus P. J. Mueller ex Wirtg.

Rosa arvensis Huds.

Rosa rugosa Thunb.

\section{Rosa rubiginosa subtype}

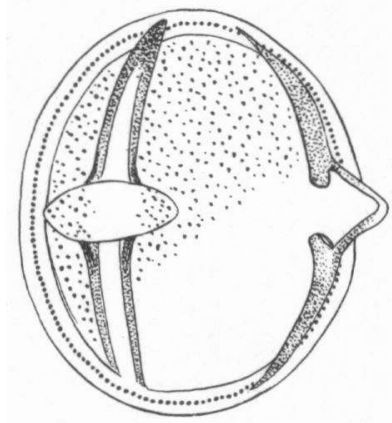

Bunde

J. Th de Smidt, Lapland N. 21 $093013 \mathrm{~B}$ [U]

Onderste Bos (Epen)

Utrecht .

Plate IB; Fig. 6

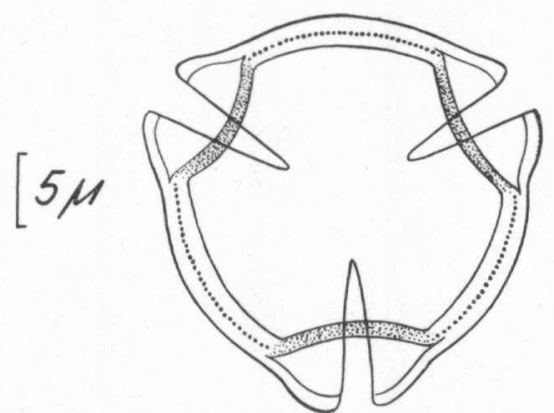

Fig. 6. Rosa rubiginosa $\mathrm{L}$.

Diagnosis: max. length 28-32 $\mu$; P.A.I.: $0.25-0.35$ Species studied Rosa rubiginosa $\mathrm{L}$.

\section{Utrecht}

\section{Rubus chamaemorus type}

Plate I E; Fig. 7
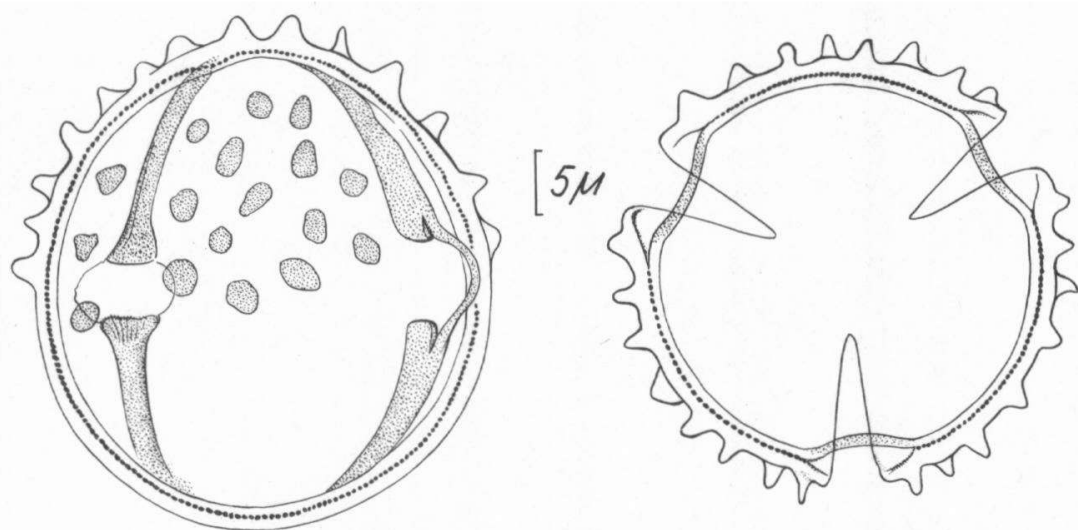

Fig. 7. Rubus chamaemorus L.

Diagnosis: tricolporate; fastigiate; echinate, verrucate, or gemmate; intrastriate, only visible with phase contrast; costae colpi; C.I. > 4; spheroidal-prolate spheroidal; eq. view: oval; pol. view: circular. Absent: operculum.

Species studied

Rubus chamaemorus $\mathrm{L}$.

Herb. Lindeman et van Royen 140

Diagnosis: $m: e=5 \mu$; max. length: 35-4l $\mu$; P.A.I.: 0.25-0.32; structural elements: max. length $1.7 \mu$, diameter $3.3 \mu$. 


\section{Rosa canina type}

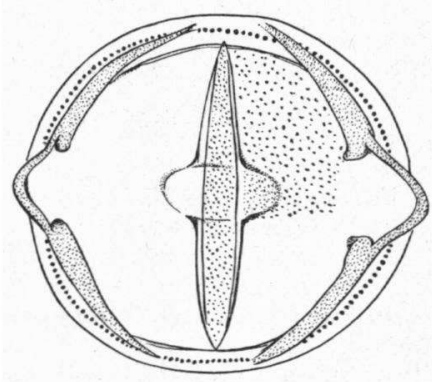

Plate IC; Fig. 8

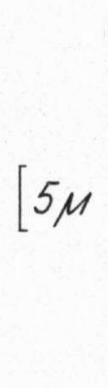

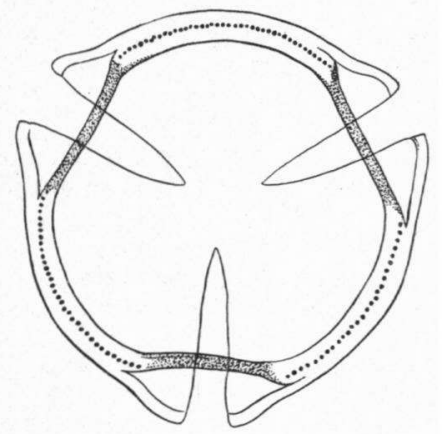

Fig. 8. Rosa canina L.

Diagnosis: tricolporate; fastigiate; psilate; intrastriate mostly only visible with phase contrast; costae colpi; costae endocolpi; operculate; G.I. $>4$; suboblate-oblate spheroidal; eq. view: ovalrhomboidal; pol. view: circular; max. length: 25-32 $\mu$; P.A.I.: $0.17-0.30$.

Species studied

Rosa canina L.

Bunde

\section{Rosa gallica type}

Plate ID; Fig. 9

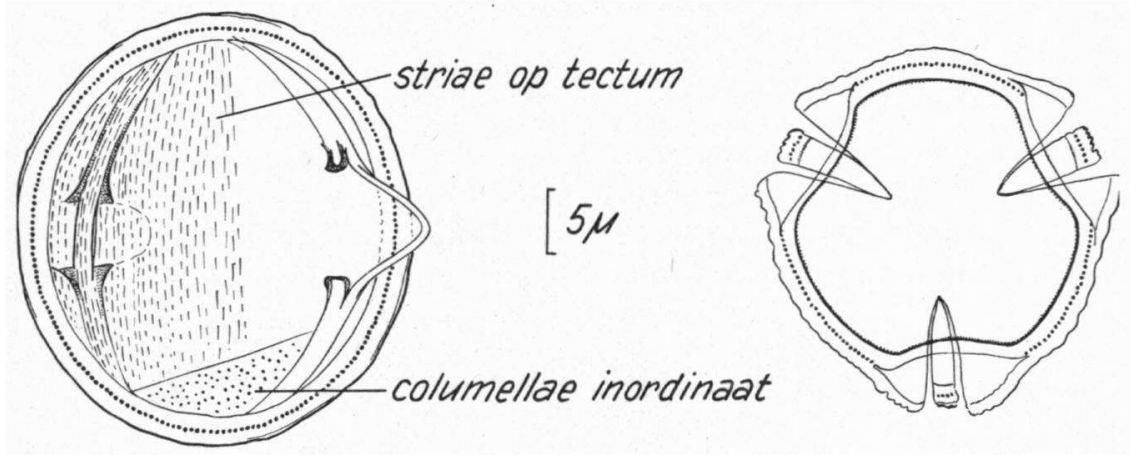

Fig. 9. Rosa gallica L.

Diagnosis: tricolporate; fastigiate; striate; costae colpi; operculate; C.I. $>4$; oblate spheroidal-prolate spheroidal; eq. view: ovalrhomboidal; pol. view: circular; max. length: 27-34; P.A.I.: $0.25-0.35$.

Species studied

Rosa gallica $\mathrm{L}$.

\section{Yougoslavia}

Potentilla type (FAegri and Iversen, 1964)

Diagnosis: tricolporate (stephanocolporate); fastigiate; striate; operculate; C.I. > 4; prolate spheroidal-prolate; eq. view: oval- 
TJ. REITSMA

rhombcidal; pol. view: circular-semiangular-interhexagonal-subangular; P.A.I.: $0.1-0.4$.

Absent: costae colpi.

KEY TO THE SUBTYPES

1 a Tectum at the pole and in the intercolpium of uniform breadth . . . 2

b Tectum at the pole twice as broad as in the intercolpium . . . . . .

a str. . . . . . . . . Potentilla sterilis subtype b Striae not anastomosing . . . . . . Fragaria vesca subtype

3 a Operculum protruding from the fastigium ..........

b Operculum not protruding from the fastigium . . . . . . . .

Potentilla sterilis subtype

Plate I F; Fig. 10
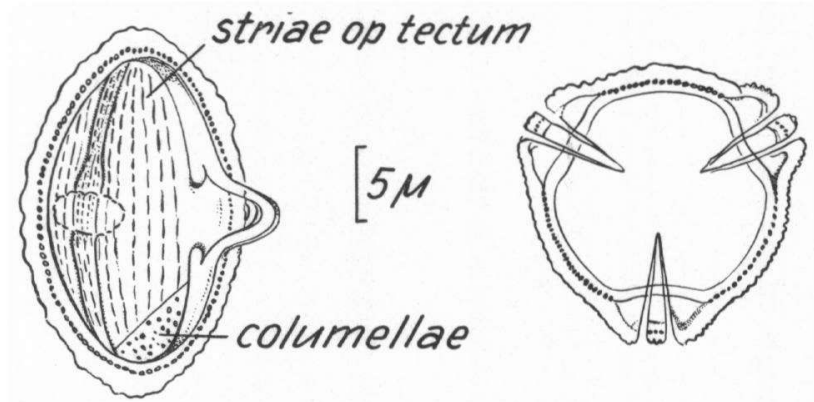

Fig. 10. Potentilla sterilis (L.) Garcke

Diagnosis: $m: e=0.5-0.7$; max. length: $22-32 \mu$; eq. view: ovalrhomboidal; pol. view: circular-semiangular.

Species studied

Potentilla sterilis (L.) Garcke

Potentilla recta $\mathbf{L}$.

Potentilla intermedia $\mathrm{L}$.

\author{
Sötenich (Germany) \\ 42002A [U] \\ Sötenich (Germany)
}

Plate IG; Fig. 11

Comarum palustre subtype

Diagnosis: $m: e= \pm 0.5$ max. length $21-27 \mu$; eq. view: oval; pol. view: circular-interhexagonal.

Species studied

Comarum palustre $\mathrm{L}$.

Loosdrecht; Terschelling; Maarsseveen

Discussion

Following Scopoli (1772), Baillon (1869), Bentham and Hooker (1865), Focke (1888) and Wolf (1908) transmit the genus Comarum to the genus Potentilla: Potentilla palustris (L) Scop.

This is perfectly justified by the pollen morphological results. 

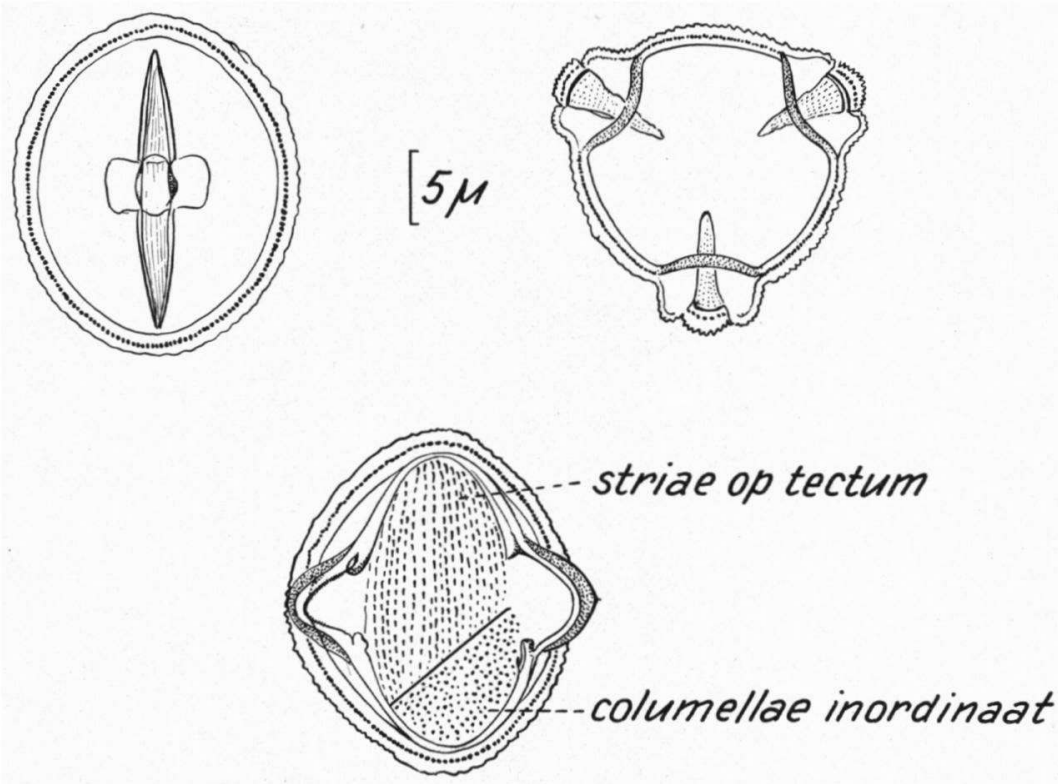

Fig. 11. Comarum palustre L.

Fragaria vesca subtype

Fig. 12
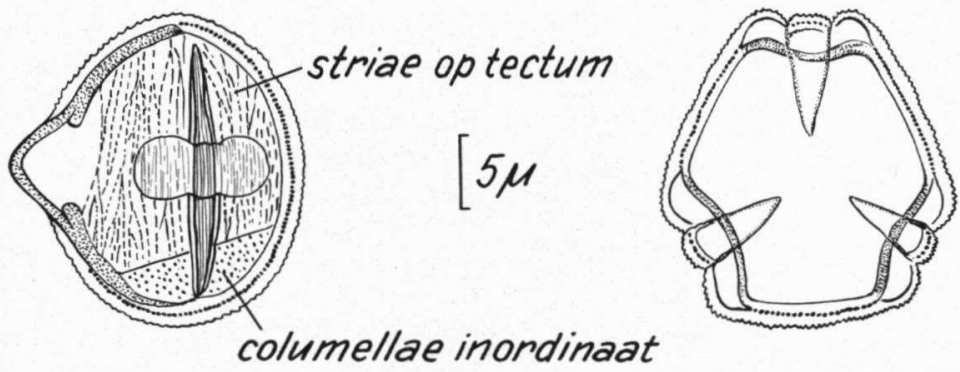

Fig. 12. Fragaria vesca $\mathrm{L}$.

KEY TO THE SPECIES

1 a Longest axis 18-25 $\mu$; endocolpus; $m: \epsilon=0.2-0.4 \ldots 2$

b Longest axis 25-31 $\mu$; endoporus; $m: e=0.5-0.75 . . . . .3$

2 a Pol. view: interhexagonal .......... Fragaria vesca b Pol. view: circular . . . . . . . . . . . Potentilla reptans

3 a Pol. view: subangular . . . . . . . . . Fragaria moschata b Pol. view: circular. . . . Potentilla tabernaemontani

Species studied

Fragaria moschata Duch.

Fragaria vesca $\mathrm{L}$.

Potentilla tabernaemontani Aschrs.

Potentilla reptans $\mathrm{L}$.
105106B [U]

Utrecht

Bemelerberg

Rhenen; Maarn 


\section{Potentilla anserina subtype}
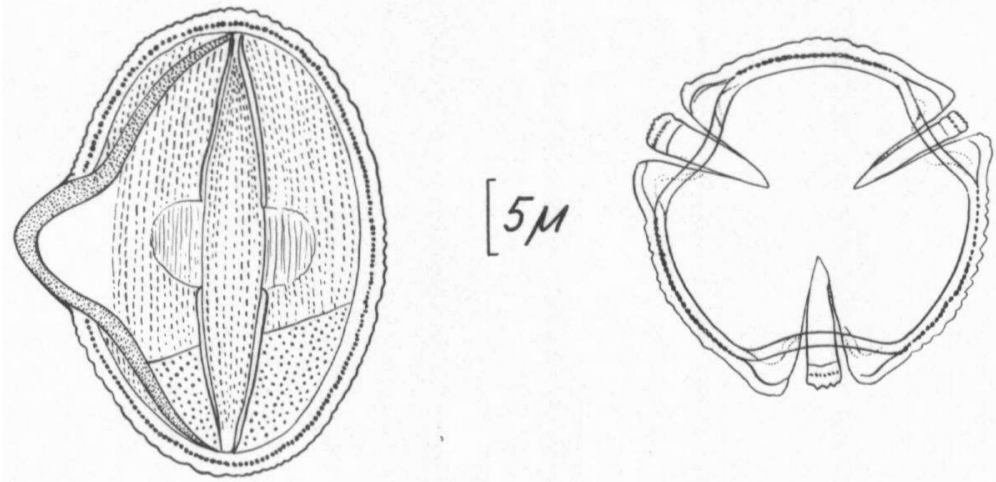

Fig. 13. Potentilla erecta (L.) Räuschel

Diagnosis: $m: e= \pm 0.5$; longest axis $22-38 \mu$; eq. view: oval; pol. view: circular.

Species studied

Potentilla anserina $\mathrm{L}$.

Potentilla argentea $\mathrm{L}$.

Potentilla anglica Laich

Potentilla erecta (L.) Räuschel

Potentilla norvegica $\mathrm{L}$.

Westbroek; Utrecht

Hilversum; Dortenbachtal (Germany) 149472B, [U]

Ginkelse heide; Maarn

Hilversum; 09644B [U]

Geum type (Faegri and Iversen, 1964)

Diagnosis: tricolporate; fastigiate; striate; C.I. $>4$; suboblateprolate; eq. view: oval-rhomboidal; pol. view: circular-semiangular.

Absent: operculum; costae colpi.

KEY TO THE SUBTYPES

Costae endocolpi present .............. Geum suktype

Costae endocolpi not present ........... Dryas subtype

\section{Geum subtype}

Plate IIB; Figs. 14, 15

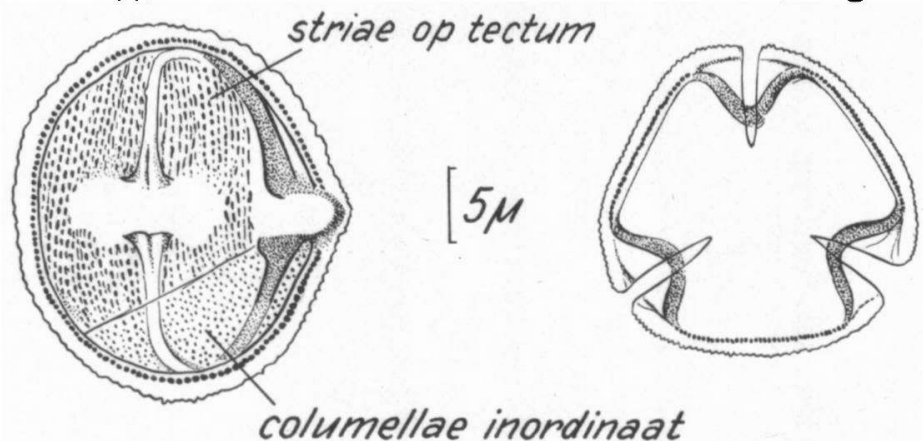

Fig. 14. Geum urbanum L. 


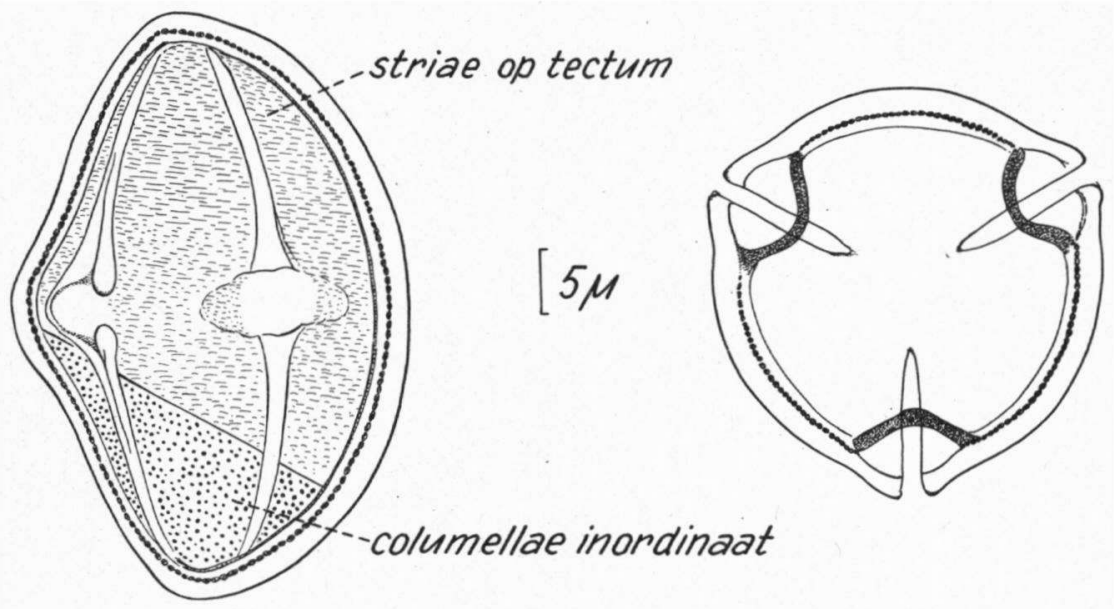

Fig. 15. Agrimonia eupatoria L.

Diagnosis: prolate spheroidal-prolate; eq. view: oval; pol. view: circular-semiangular; P.A.I.: $0.25-0.45$.

KEY TO THE GENERA AND SPECIES

1 a longest axis $22-33 \mu$. . . . . . . . . . . . . . . .

b longest axis $35-60 \mu$. . . . . . . . . . . . . . . . . .

2 a longest axis $22-28 \mu ; m: 3-3.5 \mu$. . . . . . . Geum urbanum

b longest axis $28-33 \mu m: 2.2-2.8 \mu$. . . . . . . . . . Geum rivale

3 a longest axis $35-50 \mu$; thickness exine $2.8 \mu$. . Agrimonia eupatoria

b longest axis $50-60 \mu$; thickness exine $3.5 \mu$. . . Agrimonia odorata

Species studied

Geum urbanum L.

Geum rivale $\mathrm{L}$.

Agrimonia eupatoria L.

Agrimonia odorata $\mathrm{L}$.

\section{Dryas subtype}

Utrecht

Apeldoorn

Terziet.

Th. H. ten Berge 526

Plate IIC; Figs. 16, 17
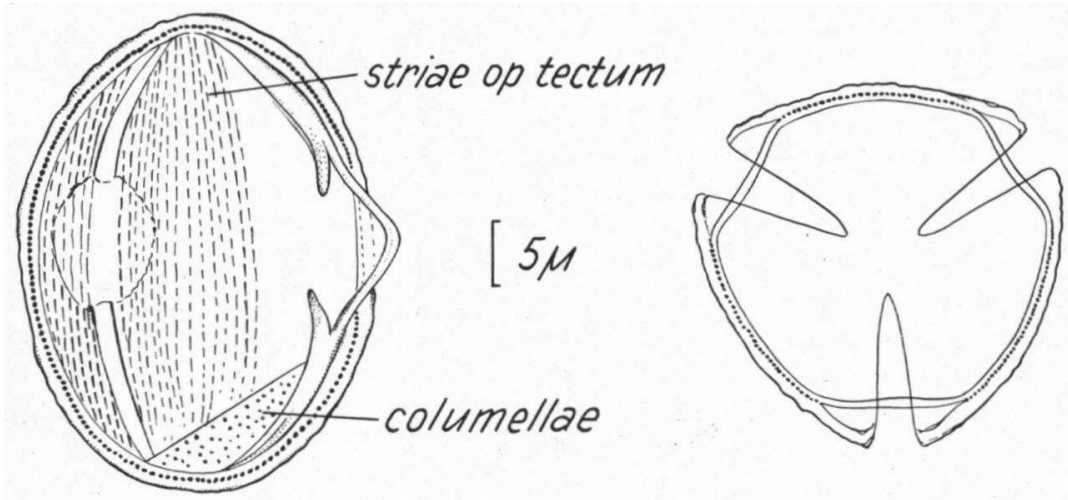

Fig. 16. Dryas octopetala L. 

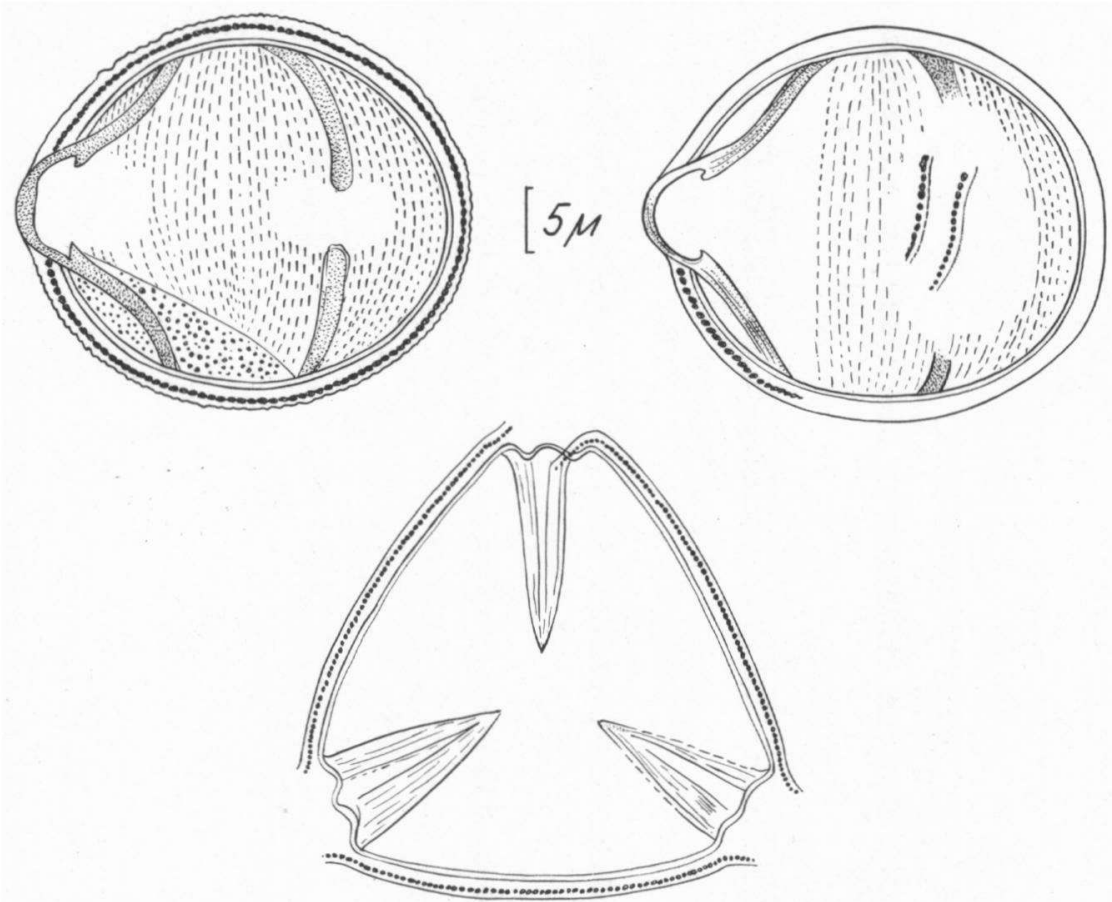

Fig. 17. Prunus avium L.

Diagnosis; suboblate-prolate spheroidal; eq. view: oval-rhomboidal; pol. view: circular; longest axis; $24-46 \mu$; P.A.I.: $0.13-0.35$.

Species studied

Dryas octopetala $\mathbf{L}$.

Physocarpus opulifolius (L.) Maxim.

Prunus avium L.

Prunus cerasus L. var. austera $\mathrm{L}$.

Prunus spinosa $\mathrm{L}$.

Prunus persica (L.) Batsch.

Prunus padus L.

Prunus serotina Ehrl.
Leg. Stud. Biol. in itinere

Helv. 109, 1913

Culture

Beek, Montferland

Utrecht

Utrecht

cult.

Utrecht

Utrecht

\section{Discussion}

Erdtman, Berglund, and Praglowski (1961), Faegri and Iversen (1964) and ERdTMan (1943) give a description of Dryas octopetala. They all state that the longest axis is less than $25 \mu$. The grains studied here, however, have a length of $30-36 \mu$. It is known though, that the size of pollen grains can be depend on polyploidy (ERDTMAN 1963).

Böcher and LARSEN (1955) found in the Alps near Col du Pillon tetraploid forms of Dryas octopetala: $2 n=36$, beside diploid plants: $2 n=18$. Different authors like $\mathrm{R}$. Czapik, in a publication of SkALINSKA et al. (1955) and Löve and LöVe (1956) have found in the North only diploid plants: $2 n=18$. 
TJ. REITSMA: Pollen morphology of some european Rosaceae
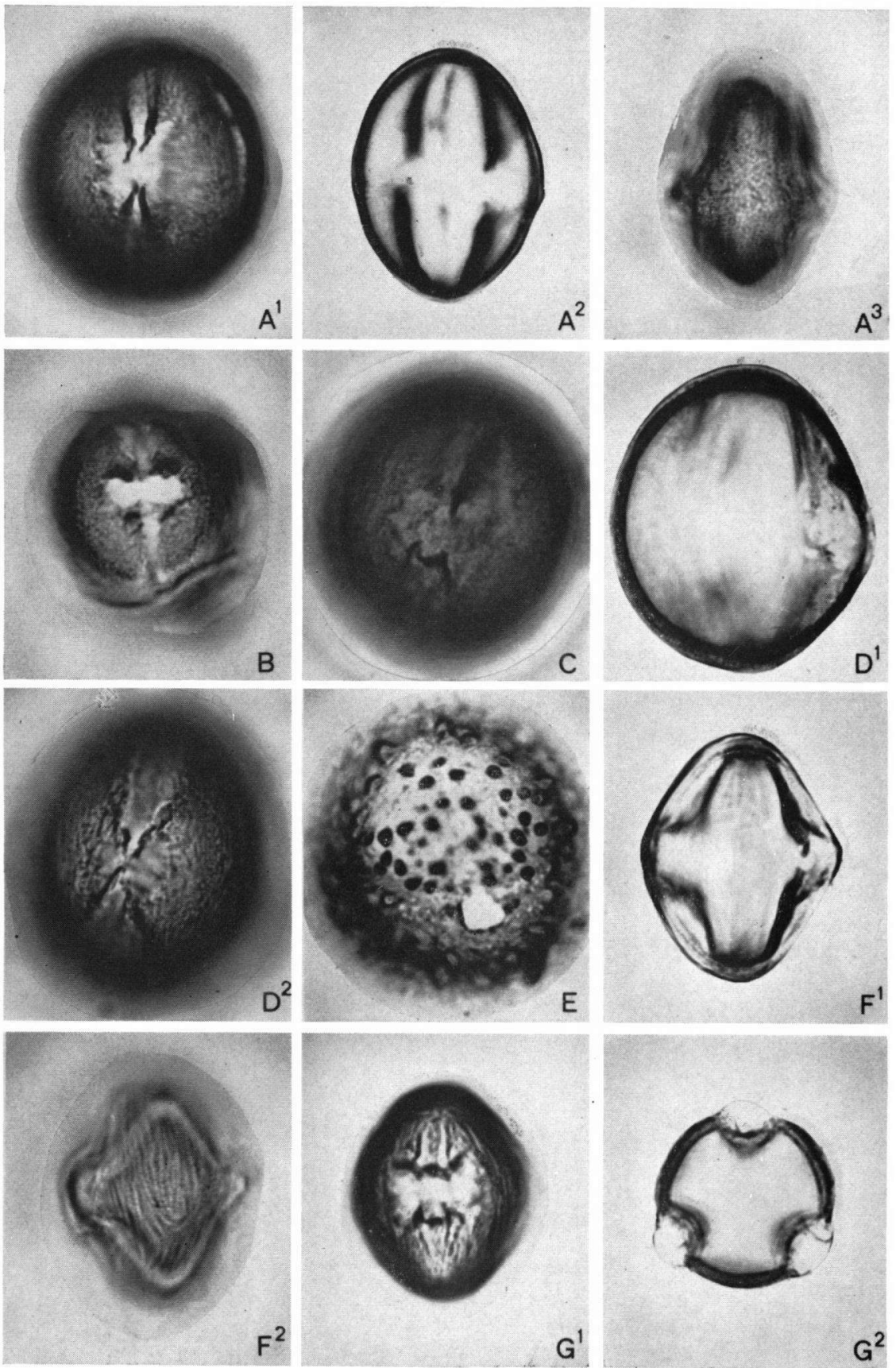

$\mathrm{A}^{1}$ Rosa arvensis

$A^{2,3}$ Rubus idacus

B Rosa rubiginosa

C Rosa canina

Facing p. 302
$D^{1,2}$ Rosa gallica

E Rubus chamaemorus

F1,2 Potentilla sterilis

G1,2 Comarum palustre

PLATE I 

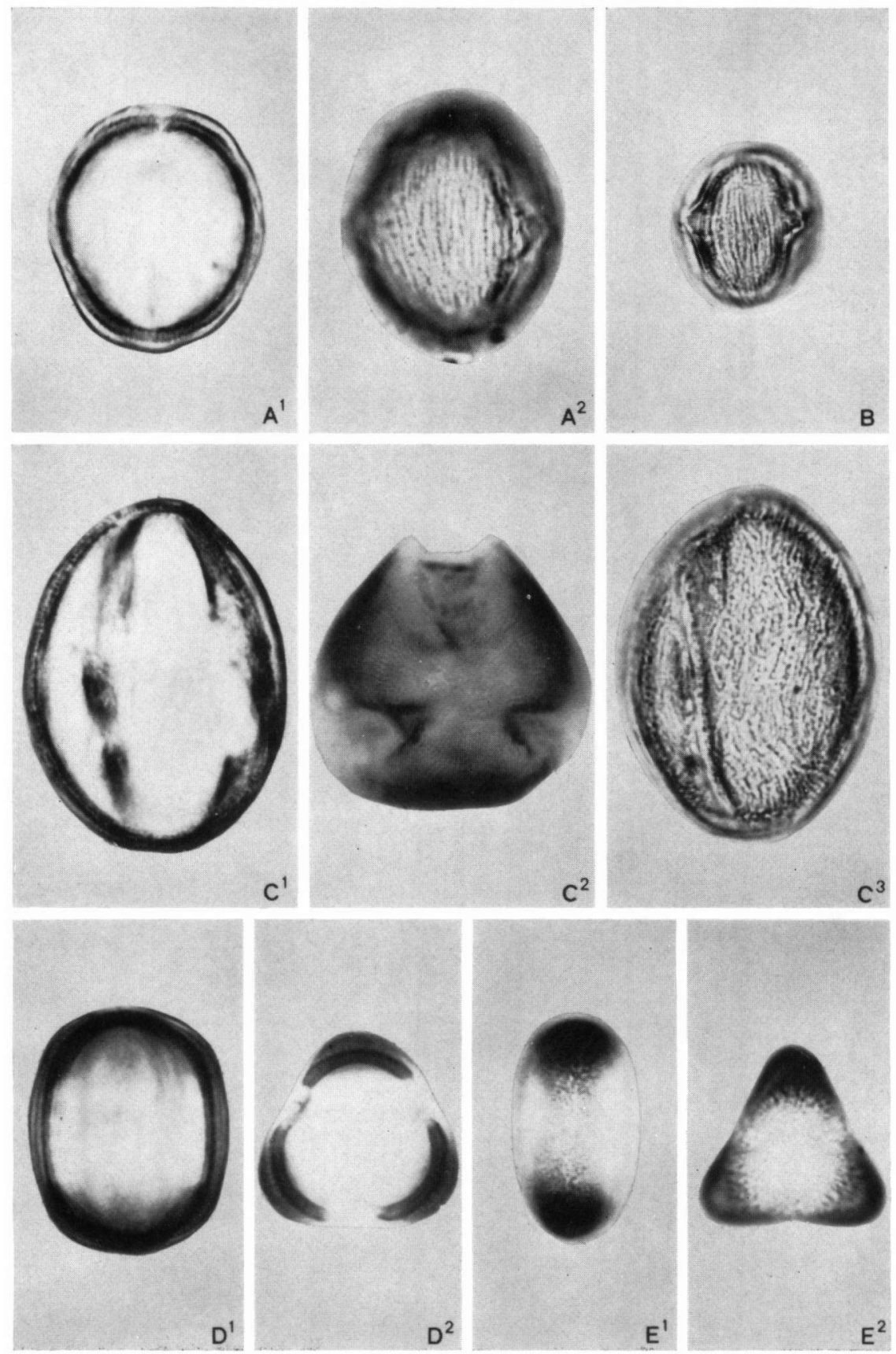

$A^{1,2}$ Potentilla anserina

B Geum urbanum

$\mathrm{C}^{2,3}$ Dryas octopetala

C $^{1}$ Prunus cerasus

$D^{1,2}$ Alchemilla glabra

$E^{1,2}$ Aphanes arvensis

PLATE II 

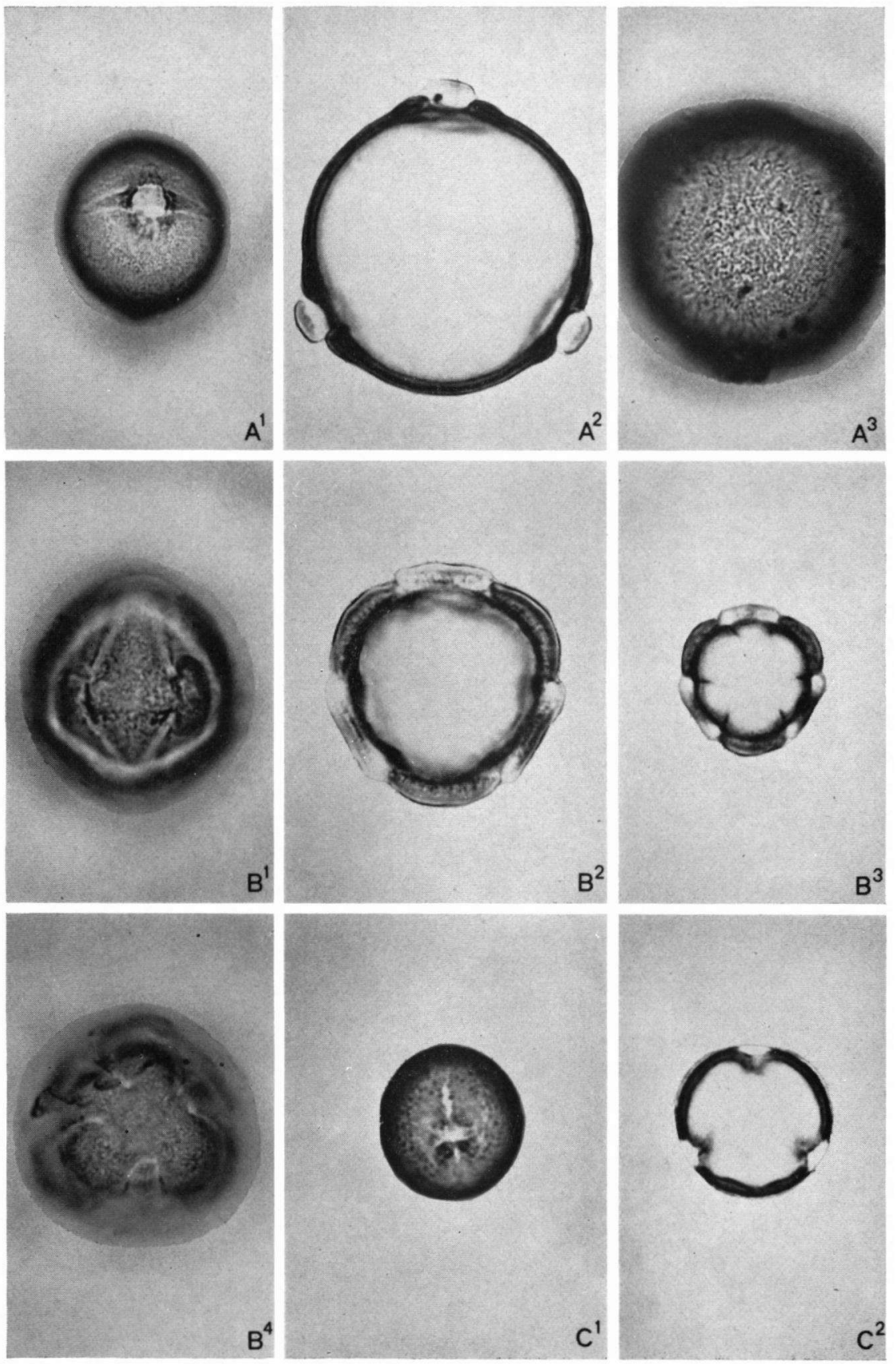

$A^{1,2,3}$ Sanguisorba minor $\mathrm{B} 1,2,3,4$ Sanguisorba officinalis C1,2 Filipendula ulmaria

PLATE III 
Probably this is the reason that the axis is shorter in those grains previously examined.

A pollen morphological and cytological study is necessary to come to any conclusion.

\section{Alchemilla type}

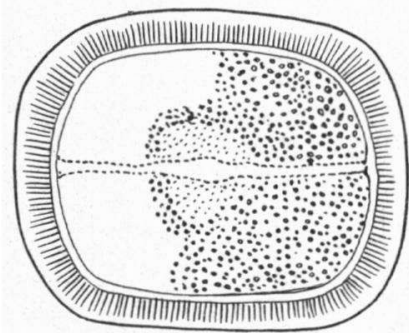

Fig. 18. Alchemilla glabra Neygens

Diagnosis: Tricolporate, sometimes tricolpate; fastigiate; Intrastriate, only visible with phase contrast; G.I. $<3$; endoporus \pm circular; columellae in intercolpium higher than those at the poles; subprolate-prolate; eq. view: rectangular-compressed oval; pol. view: intersubangular.

Absent: operculum

KEX TO THE SUBTYPES

Pollen grain with costae colpi; colpus membrane nudate

Polle . . . . . . . . . . . . . Alchemilla subtype

Pollen grain without costae colpi; colpus membrane granulate . . . . .

\section{Alchemilla subtype}

Plate IID

Species studied

Alchemilla glabra Neygenf.

Reeuwijkse plassen

\section{Aphanes subtype}

Plate IIE

Species studied

Aphanes arvensis $\mathrm{L}$.

Gulperberg; Elslo

Diagnosis: Longest axis: $24-28 \mu$; P.A.I.: $0.31-0.36$.

\section{Sanguisorba type}

Diagnosis: tricolporate; fastigiate; psilate; intrastriate; mostly only visible with phasecontrast; operculate; C.I. $<3$; oblate spheroidalprolate spheroidal; eq. view oval-rhomboidal; pol. view circular Absent: costae colpi

KEY TO THE SUBTYPES

1 a Maximum width of the colpus < maximum width of the intercolpium at equatorial view; pollen grain oblate spheroidal . . . . . . . . 
b Maximum width of the colpus $>$ maximum width of the intercolpium at equatorial view; pollen grain prolate spheroidal . . . . . . . .

.......... . . . Sanguisorba officinalis subtype

\section{Sanguisorba minor subtype}

Plate IIIA; Fig. 14
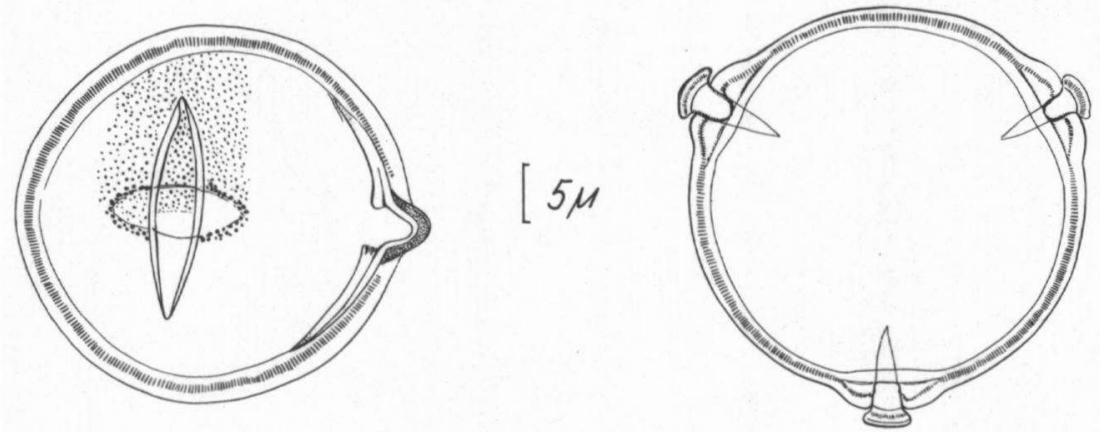

Fig. 19. Sanguisorba minor Scop.

Species studied

Sanguisorba minor Scop.

Pietersberg; Eyserbossen

Diagnosis: Longest axis: $32-39 \mu$; P.A.I.: $0.41-0.55$; end of the colpus distinct; acute.

\section{Sanguisorba officinalis subtype}

Plate IIIB; Fig. 20
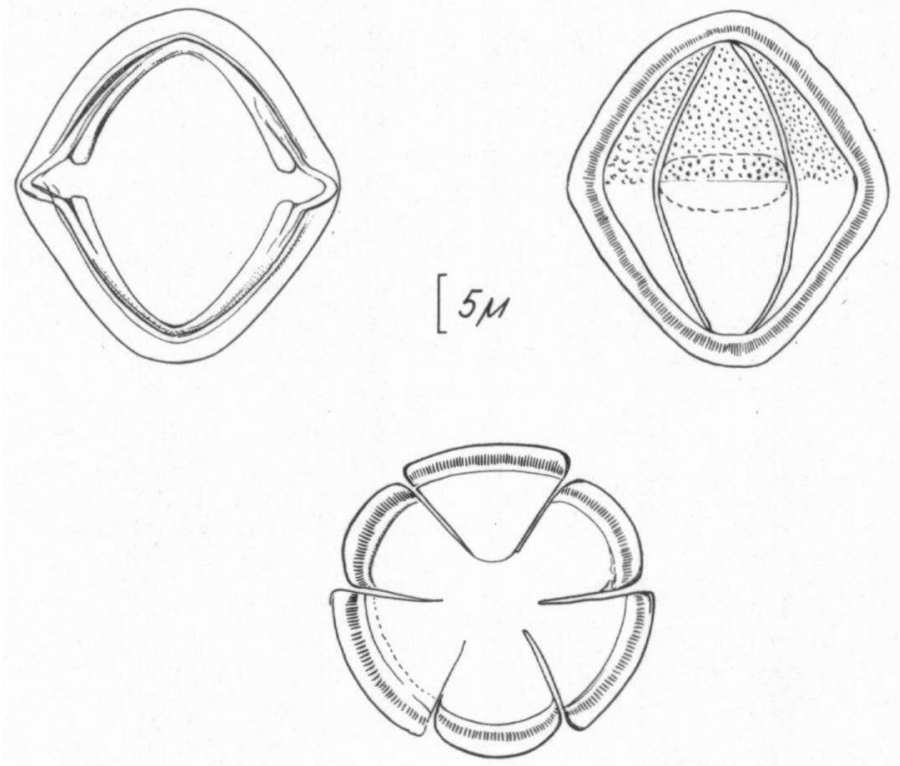

Fig. 20. Sanguisorba officinalis $\mathbf{L}$. 
Species studied

Sanguisorba officinalis $L$. Hardenberg, along the Vecht

Diagnosis: Longest axis: $28-32 \mu$ P.A.I.: $0.15-0.25$.

Discussion

Pollen grains of Sanguisorba officinalis have been described mostly as 6-colporate (FAEGri and IVERSEN (1964), ERdTMAN, BERglund and Praglowski (1961) and others). ERDTMAn and NorDBorg (1961) and ERDTMAN (1963) indicate that tetraploid plants $2 n=56$ only produce 6-colporate forms and diploid plants $2 n=28$ both 6 -colporate as 3-colborate forms.

In aperture pollen grains there are two different positions of the ectoaperture possible viz. situated opposite one other or not so. When the ectoapertures are opposite then the pollen grain has an even number of ectoapertures. When the ectoapertures are not opposite then the pollen grain has an odd number of ectoapertures.

This can be seen best in equatorial view when one of the ectoapertures is turned to the investigator as completely as possible.

The above mentioned condition does not apply to periporate, pericolpate and pericolporate pollen grains.

Studying pollen grains of Sanguisorba in such a manner, it is evident that the ectoapertures are not situated opposite one another. So the pollen grain must be tricolporate.

Also the situation of the 6 "colpi" in the pollen grain is strange viz. colpi at varying distances from each other. There are broad and narrow "intercolpia". When the two colpi with the broadest "intercolpium" are regarded as the colpus, there results a situation in which the ectoapertures are situated on uniform distance from each other, as is the case in all the remaining Rosaceous pollen grains studied. The end of the colpus is sometimes distinct. Than it is easy to see that the pollen grain possess 3 broad ectoapertures and 3 small intercolpia. It is clear now that, what was originally described as the colpus, is the nexine membrane between the edge of the colpus and the large operculum.

\section{Filipendula type}

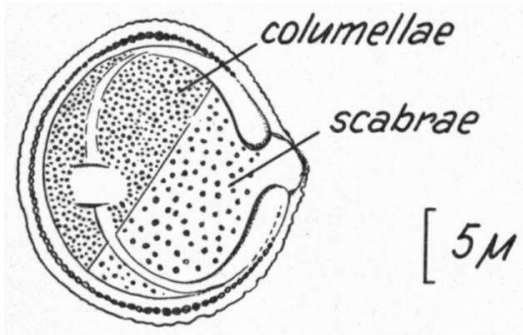

Plate IIIC; Fig. 21

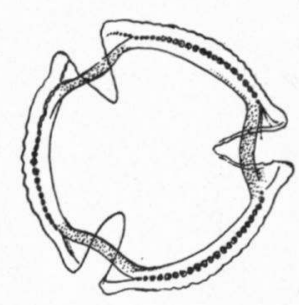

Fig. 21. Filipendula ulmaria (L.) Maxim. 
Diagnosis: tricolporate; fastigiate; scabrate; intrastriate, only visible with phase contrast; C.I. $>4$; prolate spheroidal-subprolate; eq. view: oval-rhomboidal; pol. view: circular.

Absent: operculum; costae colpi.

Species studied

Filipendula ulmaria (L.) Maxim.

Terziet

Diagnosis: max. length: 17-21 $\mu$; P.A.I.: 0.3-0.55.

Filipendula vulgaris Moench cult. Cantonspark

Diagnosis: max. length: $15-21 \mu$; P.A.I.: $0.25-0.45$.

\section{ACKNOWLEDGEMENTS}

The investigations have been carried out at the Division of Palaeobotany and Pollen Morphology of the Botanical Museum and Herbarium, State University of Utrecht, The Netherlands. The writer expresses his indebtedness to Professor Dr. F. P. Jonker for his guidance and interest. He also wishes to thank Dr. W. Punt for his valuable support and Mr. Th. Schipper who made the drawings. He is also very grateful to Mr. D. K. Ferguson, B.Sc., M.Sc., for his linguistic advise.

\section{REFERENCES}

Baillon, H. 1867-1869. Histoire des Plantes 1: 345-488.

Bentham, G. and J. D. Hooker. 1865. Genera plantarum 1, II: 600-629.

Böcher, T. W. and K. Larsen. 1955. Chromosome studies on some European Flowering Plants. Bot. Tidskr. 52: 125-132.

Campo, M. van. 1958. Bulletin de l'Institut Français d'Afrique Noir t. 20 Palynologie Africaine II: 753-760.

Erdtman, G. 1943. An introduction to Pollen Analysis. Waltham, Mass., 239 pp. 1948. Did dicotyledonous plants exist in early Jurassic times? Geol. Fören. Stockh. Förh. 70: 265-271.

1952. Pollenmorphology and Plant Taxonomy. Angiosperms. Uppsala, 539 pp.

1963. Palynology, in Vistas in Botany, 4, Pergamon Press: 23-54.

B. Berglund and J. Praglowski. 1961. An introduction to a Scandinavian pollen flora. Grana palynologica 2: 3-92.

und G. Nordmorg. 1961. Uber Möglichkeiten die Geschichte verschiedener Chromosomenzahlenrassen von Sanguisorba officinalis und Sanguisorba minor pollenanalytisch zu beleuchten. Bot. Not. 114: 19-21.

FaEGRI, K. and J. Iversen. 1964. Textbook of Pollenanalysis, second revised edition, Copenhagen, $237 \mathrm{pp}$.

Focke, W. O. 1881. in Engler-Prantl: Die Natürlichen Pflanzenfamilien 3, 3: 1-61. IVERSEN, J. and J. Troess-Smitr. 1950. Pollenmorphologischen Definitionen und Typen. Danm. Geol. Unders. ser. 4. 3 (8), 54 pp.

Kuyl, O. S., J. Muller and H. T. Waterbolk. 1955. The application of Palynology to Oil Geology with reference to Eastern Venezuela. Geologie en Mijnbouw, 3 New Series vol. 17: 49-76.

Lawalrér, A. 1958. Flore générale de Belgique 3, $440 \mathrm{pp}$.

Löve, A. and D. Löve. 1956. Cytotaxonomical Conspectus of the Icelandic Flora. Acta Hort. Gotoburg. 20: 65-290.

PunT, W. 1962. Pollenmorphology of the Euphorbiaceae with special reference to Taxonomy. Wentia 7. 116 pp.

Scopoli, I. A. 1771. Flora carniolica, 2nd ed. 1.

Skalinska, M., R. Czapik, M. Piotrowicz et al. 1959. Further studies in chromosome numbers of Polish Angiosperms (Dicotyledons). Acta Soc. Bot. Pol. 28: 487-529. 
Thomson, P. W. und H. Pflug. 1953. Pollen und Sporen des Mitteleuropäischen Tertiärs. Palaeontographica, B. 94. 138 pp.

Wolf, Th. 1908. Monographie der Gattung Potentilla. Bibliotheca Botanica 16. $714 \mathrm{pp}$.

ZAGwrj, W. H. 1963. Intern rapport van de Geologische Dienst, Haarlem. Handleiding Pollenmorphologie. 